\title{
Organoleptic properties of pineapple peel juice marinated beef (Ananas comosus L. Merr)
}

\author{
Harapin Hafid ${ }^{1}$, Peni Patriani ${ }^{2,}$, Sigit Sepriadi ${ }^{2}$, and Siti Hadrayanti Ananda ${ }^{3}$ \\ ${ }^{1}$ Department of Animal Science, Faculty of Animal Science, Halu Oleo University, J1.HEA \\ Mokodompit, Anduonohu, Kendari 93232, South East Sulawesi, Indonesia \\ ${ }^{2}$ Department of Animal Husbandry, Faculty of Agriculture, Universitas Sumatera Utara, Jl. Dr. T. \\ Mansur No.9, Medan 20222, Medan, Sumatera Utara, Indonesia \\ ${ }^{3}$ STIKES Karya Kesehatan, Anduonohu, Kendari 93232, South East Sulawesi, Indonesia
}

\begin{abstract}
Beef has a high level of toughness that is not liked by consumers. The solution to increasing beef tenderness is to soften the beef. One method for tendering the beef is by marinating using local ingredients that are easily available, abundant, and inexpensive, namely pineapple. Pineapple peel is waste from pineapple that has not been utilized and is usually discarded. In pineapple peel, there is a bromelain enzyme thought to be able to hydrolyse protein so that it can tender beef. The purpose of this study was to find out the organoleptic properties of beef using the marination with various pineapple peel juice concentrations (Ananas comosus L. Merr) namely $0 \%$, $10 \%, 20 \%$, and $30 \%$. This study used an experimental method with a Completely Randomized Design consisting of 4 treatments and 4 replications. The parameters in this study were organoleptic properties namely colour, aroma, texture, tenderness, and taste. Results of the study showed that beef marination with various pineapple peel juice concentrations had a significant difference $(\mathrm{P}<0.05)$ on taste, texture, and tenderness of beef but had no significant difference in colour and aroma $(\mathrm{P}>0.05)$
\end{abstract}

\section{Introduction}

Beef is one of the highly nutritious animal food ingredients. Beef contains high levels of protein and amino acids in almost the same ratio as the pattern needed for human growth. The need for animal protein from year to year continues to increase in proportion to the increasing population and awareness of nutritional needs. Animal protein needs can be met by consuming livestock commodities that have high protein content such as beef. According to [1] the substances contained in beef are $19-22 \%$ protein, $2.5 \%$ fat, $1.2 \%$ carbohydrate, $75 \%$ water, and $1.5 \%$ non-protein substances. In addition to the nutritional value of beef, organoleptic quality also contributes to the level of consumption by consumers.

\footnotetext{
* Corresponding author: penipatriani@usu.ac.id
} 
According to [2] beef quality has a complex effect and can be defined as beef characteristics that satisfy consumers. This shows that in addition to physical and microbiological qualities, organoleptic properties also play a role in the level of consumer preferences.

Beef is known to have a level of tenderness and toughness that varies according to beef type or location on the carcass. Beef shank is tougher than beef sirloin because there are differences in connective tissue. The connective tissue in the beef shank is denser because it has more activity [3]. High toughness beef is not liked by consumers, so it needs to be treated to increase tenderness. To tender beef and increase beef consumption, there is a need for beef processing. This can be performed by marinating beef using ingredients containing the protease enzyme.

Protease enzymes can catalyse protein breakdown. For decades, various studies on beef tenderness identified proteins, metabolic enzymes, proteolysis enzymes, structural proteins, and contraction proteins of beef [4]. The results of a study by [5] showed that pineapple contains a protease enzyme in the skin of $29-40 \%$, the content of $9-10 \%$, stems of $2-5 \%$, and crowns of $2-4 \%(\mathrm{w} / \mathrm{w})$. according to [6] stated that the bromelain enzyme has the potential to tender beef. Bromelain enzyme is easy to obtain because pineapple can produce fruit throughout the year and is spread throughout Indonesia. Therefore, the use of pineapple as an ingredient for tendering beef is an alternative that can be used by the community.

Bromelain enzyme is a protease enzyme that can hydrolyse protein to tender beef. Dark green and $100 \%$ yellow pineapple contains bromelain enzymes. Dark green pineapple contains more bromelain enzymes, while $100 \%$ yellow pineapple contains fewer bromelain enzymes than dark green pineapple [7]. Pineapple peel is agricultural waste from pineapple consumed. Pineapple peel waste has not been utilized properly. The purpose of this study was to utilize pineapple peel waste into the right formulation for marination to produce tender and acceptable beef for consumers. Based on the explanation above, a study is needed to determine the effect of marination using pineapple peel juice on the organoleptic properties of beef

\section{Methods}

The study was conducted at the Animal Product Technology Unit Laboratory of the Faculty of Animal Husbandry at Halu Oleo University and Kendari City Slaughterhouse from March to April 2019.

\subsection{Material}

The equipment used in this study were water baths, analytical scales with a capacity of $2 \mathrm{~kg}$, $\mathrm{pH}$ meter, colour score. The material used in this study was 3-years-old beef, the study sample was taken from the Slaughterhouse (RPH) of Kendari City. The materials used were $6 \mathrm{~kg}$ beef shank (round), 600 grams of pineapple peel, and 3 litters of water.

\subsection{Procedure}

The making of pineapple peel juice follows the procedure carried out by Zulfahmi (2010). Pineapple skin is washed and cut then mashed with a blender and filtered. The percentage of pineapple peel juice production is performed using the following formula Percentage of pineapple peel $(\%)=$ Penneaple peel/ water $\mathrm{x} 100 \%$. Pineapple peel needed to make juice is 100 grams, 200 grams and 300 grams. The $\mathrm{pH}$ of the beef sample used was measured, then the beef sample was cleaned of connective tissue and attached fat. The beef was then 
uniformly cut as much as 100 grams and then marinated using pineapple peel juice following the concentration of treatment for 30 minutes.

\subsection{Design}

This study used an experimental method using a Completely Randomized Design consisting of 4 treatments, each treatment consisting of 4 replications. Organoleptic testing used 25 trained panellists.

The treatments are as follows:

$\mathrm{P} 0=$ Marinated without pineapple peel juice (control) $\mathrm{P} 1=$ Marinated with 10\% pineapple peel juice (g/v) P2 = Marinated with 20\%pineapple peel juice (g/v) P3 = Marinated with $30 \%$ pineapple peel juice $(\mathrm{g} / \mathrm{v})$

\subsection{Variable}

Organoleptic is the testing of a material or product based on preferences [9-11]. Panellist testing used the like or dislike response to the experimental product which was the influence of pineapple peel juice on beef quality by 25 trained senior students from the Faculty of Animal Husbandry and had graduated from beef science and beef processing technology as panellists. The hedonic scale for organoleptic testing includes aroma, taste, texture, and tenderness (Table 1).

Table 1. Organoleptic test.

\begin{tabular}{|c|c|c|}
\hline Organoleptic variable & Hedonic scale & Criteria \\
\hline \multirow[t]{5}{*}{ Aroma } & 1 & Extremely like \\
\hline & 2 & Like \\
\hline & 3 & Moderately like \\
\hline & 4 & Dislike \\
\hline & 5 & Extremely dislike \\
\hline \multirow[t]{5}{*}{ Taste } & 1 & Extremely like \\
\hline & 2 & Like \\
\hline & 3 & Moderately like \\
\hline & 4 & Dislike \\
\hline & 5 & Extremely dislike \\
\hline \multirow[t]{4}{*}{ Texture } & $\begin{array}{l}1 \\
2 \\
\end{array}$ & $\begin{array}{l}\text { Very soft } \\
\text { Soft }\end{array}$ \\
\hline & 3 & Medium \\
\hline & 4 & Rough \\
\hline & 5 & Very Rough \\
\hline \multirow[t]{5}{*}{ Tenderness } & 1 & Very Tender \\
\hline & 2 & Tender \\
\hline & 3 & Medium \\
\hline & 4 & Tough \\
\hline & 5 & Very Tough \\
\hline
\end{tabular}




\subsection{Data analysis}

Data were tabulated and analyzed using analysis of variance. If the treatment influences the evaluated variable, then it is continued with the lowest significant difference test [12].

\section{Results and discussions}

The organoleptic assessment aims to determine the score of beef with different concentrations of pineapple peel juice to get the best organoleptic properties. The assessment was performed using a hedonic test with a scale of 1-5). The results of the study can be seen in Table 2 below

Table 2. The average score of colour, taste, texture, and tenderness of beef marination with various pineapple peel juice concentrations.

\begin{tabular}{|c|c|c|c|c|}
\hline \multirow{2}{*}{ Variable } & \multicolumn{4}{|c|}{ Treatment } \\
\cline { 2 - 5 } & P0 & P2 & P3 & P4 \\
\hline Colour & $2.75 \pm 0.77$ & $2.80 \pm 0.61$ & $2.82 \pm 0.66$ & $2.95 \pm 0.78$ \\
\hline Aroma & $2.50 \pm 0.74$ & $2.50 \pm 0.52$ & $2.51 \pm 0.73$ & $2.55 \pm 0.85$ \\
\hline Taste & $2.75 \pm 0.82^{\mathrm{a}}$ & $2.80 \pm 0.77^{\mathrm{a}}$ & $1.82 \pm 0.80^{\mathrm{b}}$ & $2.19 \pm 0.83^{\mathrm{b}}$ \\
\hline Texture & $2.65 \pm 0.58^{\mathrm{a}}$ & $2.59 \pm 1.11^{\mathrm{a}}$ & $1.90 \pm 0.57^{\mathrm{b}}$ & $2.13 \pm 0.66^{\mathrm{b}}$ \\
\hline Tenderness & $2.65 \pm 0.65^{\mathrm{a}}$ & $2.60 \pm 0.76^{\mathrm{a}}$ & $1.75 \pm 0.63^{\mathrm{b}}$ & $2.20 \pm 0.78^{\mathrm{b}}$ \\
\hline
\end{tabular}

Remarks: Numbers with different superscripts show real differences $(\mathrm{P}<0,05)$

\subsection{Colour}

Colour is used as an indicator of freshness or maturity. The quality of mixing or processing can be characterized by the presence of uniform and even colours in cooked beef, which is generally in grey. The results of statistical analysis showed that beef marination with various pineapple peel juice concentrations had a significant difference $(\mathrm{P}<0,05)$ on taste, texture, and tenderness of beef but had no significant difference in colour and aroma $(\mathrm{P}>0,05)$. Beef colour plays an important role because it is associated with freshness and consumer acceptance. Fresh beef will show a bright red colour while stale beef shows a darker colour.

The panellist assessment score shows that the score of beef colour ranges from 2.75 to 2.95 which means that it is liked and has good acceptance. The lowest colour score was in control and the highest in P3 or marinated with 30\% pineapple peel juice. This shows that beef marination with pineapple peel juice up to $30 \%$ did not affect the assessment of panellists on the organoleptic properties of beef. From the perspective of consumer acceptance, beef colour is one of the main factors [13]. This means that the content of myoglobin in beef is a major factor affecting beef colour, so the more myoglobin content, the beef will be redder. The colourant in beef or myoglobin is a conjugated protein compound that has a purple colour. This purplish-red colour will turn bright red if myoglobin comes in contact with oxygen and forms oxymyoglobin. According to [14] bromelain causes beef to have a brownish colour due to oxidation to metmyoglobin. Beef also tends to be lighter and also turns into a brown hue. In this study, the addition of pineapple peel juice did not cause significant colour changes when compared to control and consumer acceptance in a range that was good enough or quite preferred. 


\subsection{Aroma}

The aroma is another important characteristic in assessing the level of consumer acceptance of a food product. The aroma of beef must be fresh, not smelly or sour, but the smell of fresh beef. The results of statistical analysis showed that beef marination with various pineapple peel juice concentrations had no significant difference $(\mathrm{P}>0.05)$ on the beef aroma. Panellist assessment results showed that the beef aroma score ranged from $2.50-2.55$. The highest aroma score was in P3 and lowest in P0. Fresh beef has the smell of fresh blood. According to [15] the beef aroma is a mixed effect of triacylglycerol lipolytic activity, oxidative rancidity of unsaturated fatty acids, and protein degradation products that accumulate in fat tissue. The beef in this study has a good organoleptic score. Taste is a determining factor in the acceptability of consumers for food products.

\subsection{Taste}

The results of statistical analysis showed that beef marination with various pineapple peel juice concentrations had a significant difference $(\mathrm{P}<0.05)$ on beef taste. Panellist assessment results showed that the taste score of beef ranged from 1.82 to 2.80 . This shows that beef marination with pineapple peel juice up to $30 \%$ influences panellist assessment of beef taste. The lowest taste assessment score was P2 and the highest was in P. The main cause of the decline in food quality, especially beef, was allegedly due to changes in fat components through the process of fat oxidation or hydrolytic reaction derived from enzymatic extracts of pineapple peel, resulting in decreased flavour quality. The taste of pineapple peel juice marinated beef in this study was included in the good category.

\subsection{Texture}

The beef texture shows the smooth and rough surface of the beef after being sliced, both on fresh and cooked beef. The results of statistical analysis showed that beef marination with various pineapple peel juice concentrations had a significant difference $(\mathrm{P}<0.05)$ on beef texture. This shows that the marinated beef in pineapple peel juice up to a level of $30 \%$ influences the assessment of panellists on the texture of beef. The score of beef texture in this study ranged from 1.90-2.65. During marination, anaerobic glycolysis is thought to cause lactic acid formation. The more lactic acid accumulates, the more denatured protein so that it is unable to bind water. The less water is bound by protein in the beef, the lower the beef tenderness. This is in line with a study by [16-17] which showed that the bromelain enzyme can affect muscle texture. According to [18] the enzymes of papain and bromelain can cut connective tissue proteins and myofibrils, causing an increase in hydroxyproline and free amino acid content of beef cuts. In this study, the results showed that marination with pineapple peel juice was quite good and was accepted by panellists in the organoleptic test.

\subsection{Tenderness}

Tenderness is the most important thing in determining beef quality because it is related to beef palatability which is related to how easily beef is cut into small pieces so that when chewed it is easy to swallow. The results of statistical analysis showed that beef marination with various pineapple peel juice concentrations had a significant difference $(\mathrm{P}<0.05)$ on beef tenderness. The results of the panellist assessment showed that the beef tenderness score ranged from 1.75 to 2.65. The highest score is in P0 and the lowest in P2. According 
to [19- 21] stated that bromelain enzyme can hydrolyze beef myofibril protein and can be used as a hydrolysis agent for beef. This shows that the bromelain enzyme is a protease that can degrade beef collagen so that it can tender the beef. In this study, the score of pineapple peel juice marinated beef was better than control which was in the tender category so that it was accepted by panellists or consumers.

\section{Conclusions}

Based on the results and discussion, it can be concluded that beef marination with various pineapple peel juice concentrations had a significant difference $(\mathrm{P}<0.05)$ on taste, texture, and tenderness of beef but had no significant difference on colour and aroma $(\mathrm{P}>0.05)$. Beef marination with pineapple peel juice was quite effective in increasing the organoleptic properties of beef, especially in taste, texture, and tenderness. Further studies need to be performed with higher concentrations of pineapple peel juice to get good beef quality.

Acknowledgments to the Universitas Sumatera Utara and Halu Oleo University for facilitating this research

\section{References}

1. H. Hafid dan A. Syam, Buletin Peternakan, 31, 209-217 (2007)

2. J.F. Hocquette, R. Botreau, B. Picard, A. Jacquet, D.W. Pethick and N.D Scollan, Meat Science, 92,197-209 (2012)

3. H. Hafid, Alfabeta, Bandung, 23-25 (2017)

4. N. Guillemin, M. Bonnet, C. Jurie, B. Picard, Journal of Proteomics, 75, $352-365$ (2011)

5. S. Ketnawa, Phanuphong, Chaiwut, S. Rawdkuen, Food and Bioproducts Processing, 90 385-391 (2012)

6. M. Ha, A. A.E., Din, Bekhit, A. Alan Carne, D.L Hopkins, Food Chemistry, 134, 95105 (2012)

7. M. Essay, Fakultas Sains Dan Teknologi, Universitas Islam Negeri Maulana Malik Ibrahim, Malang (2010)

8. M. Zulfami, Jurnal Peternakan, 9, 1 (2010)

9. H. Hafid, A Napirah, S M Sarifu, Rahman, Inderawati, Nuraini dan Hasnudi, JITV, 23, 202-9 (2018)

10. H. Hafid, P.Patriani, Nuraini, Norma, S.H Ananda, and Inderawati, IOP Conf. Series: Earth and Environmental Science, 454, 012057 (2020)

11. H. Hafid, P. Patriani, Nuraini, S.H. Ananda, IOP Conf. Series: Earth and Environmental Science, 749, 012003 (2021)

12. Mattjik, Ahmad Ansori and Sumertajaya, Made (IPB Press, Bogor, 2006)

13. R.S. Chaurasiya, P.Z. Sakhare, N. Bhaskar, and H.U Hebbar, J Food Sci Technol, 52, $3870-3880$ (2015)

14. K.Z Nadzirah, S. Zainal, A. Noriham, and I Normah, International Food Research Journal, 23, 1590-1599 (2016)

15. J.D. Merthayasa, I.K. Suada, K.K. Agustina, Indonesia Mediscus veterinus, 4, 1 (2015)

16. N. Gokoglu, P. Yerlikaya, I. Ucak, H.A. Yatmaz, Springer Science, 11, 347-353 (2016)

17. M. Maghfiroh, R.K. Dewi, E. Susanto (Fakultas Peternakan Universitas Lamongan: 
Lamongan, 2016)

18. D. Istrati, C. Vizireanu, R. Dinică, Journal of Agroalimentary Processes and Technologies, 18, 70-75 (2012)

19. D.S. Hage, J.A. Anguizola, C. Bi, R. Li, R. Matsuda, E.P. Papastavros. E. faunmiller, J. Vargas, X. Zheng, J Pharm Biomed Anal, 1, 13 (2012)

20. G.A. Sullivan, C.R. Calkins, Meat Sci, 85, $730-734$ (2010)

21. Z.I.M. Arshad, A. Amid, F. Yusof, I. Jaswir, K. Ahmad, Appl Microbiol Biotechnol, 98, 7283-7297 (2014) 